\title{
Risk reduction based on controlling technologies on industrial enterprises
}

\author{
T.A. Khudyakova ${ }^{1, *}$, and $A . V$. Shmidt $^{1}$ \\ ${ }^{1}$ South Ural State University, Chelyabinsk, Russia
}

\begin{abstract}
During the global economic instability, demand in developing toolkit which helps to mitigate the negative impact of environmental factors on efficiency of activity of the enterprise is increasing dramatically. However, in practice implementation of any of the tools causes the growth of additional costs, which, for purposes of effective functioning of mini-economic system must be covered by the profit's increase from the introduction of this toolkit. The task's implementation was achieved by processing a significant amount of scientific and statistical literature and calculation of integral indicators of the effectiveness of controlling system's implementation at the enterprises. The analysis revealed a positive effect of the implementation of controlling system on the quality of decisions, efficiency of management, productivity, investment attractiveness, effectiveness of workflow and financial stability, and calculated the average integral efficiency indicators. The obtained results allow to make an unambiguous conclusion about the effectiveness of the controlling system's implementing, which is especially important during the period of economic globalization and the growth of perturbations in the external environment, the efficiency reserves identified in the operation of the controlling system can and should be a certain buffer to reduce the negative impact of external factors on the sustainability of the enterprise.
\end{abstract}

\section{Introduction}

In the times of the crisis caused by the external environment fluctuations the geopolitical and socioeconomic area variability increases dramatically. The disturbances that come from the outside have a significant impact on the Russian industrial cluster condition, reducing its financial and economic sustainability. Controlling system is aimed at neutralizing the impact of the disturbances on company activity as the terminal segment of economy. However, changes in the company structure and functionality will result in higher costs. In this regard, before the stage of sustainability controlling system designing the stakeholders should understand the general trends of the company efficiency rising due to the measures taken. The experience of leading Russian and foreign companies that have already been using controlling system in their activity can be useful in this case. Analysis and synthesis of data they have on the rise in the company efficiency, as well as the common trends identification can simplify the prediction phase greatly.

\section{Theoretical framework and literature review}

Nowadays the methodological issues in the field of controlling systems formation and development as the basis for enhancing business entity sustainability by means of preventive control, aimed at reducing the negative effects of disturbances coming from the enterprise operational environment, are not given much attention to. There are no methodological approaches to the company controlling system construction ensuring the highest possible elimination of the environmental uncertainty, aimed at improving its financial and economic sustainability. The controlling models implemented in some companies perform mostly recording, controlling and planning functions, without predicting the environmental uncertainty impact on the financial and economic performance of the company. This is due to the controlling evolution in the Russian Federation: the first controlling systems introduction was mentioned only after perestroika in Russia. Only at the turn of the XXI century the approaches to the business entity strategic management began to form and dominate the recording concept. That is why there is practically no quantitative assessment of the controlling system introduction impact on the company financial and economic activity in research papers. Only a small group of Russian researchers tried to quantify the impact of the controlling system introduction on the business entity activity efficiency, despite the fact that the positive aspect of the controlling introduction is mentioned almost in all modern scientific studies.

Corresponding author: khudiakovata@susu.ac.ru

C) The Authors, published by EDP Sciences. This is an open access article distributed under the terms of the Creative Commons Attribution License 4.0 (http://creativecommons.org/licenses/by/4.0/). 


\section{Materials and methods}

\subsection{Analysis of the impact of research on the introduction of the controlling system to the efficiency of the enterprise}

In their article "Controlling in Russia" Falko S., Russell $\mathrm{K}$. and L. Levin, considered to be the founders of the Russian controlling, noted that according to experts estimations due to introducing a controlling system in the company "it is possible to ensure a $15-30 \%$ growth of integrated performance indicators" [1]. And the controlling introduction at the enterprises engaged in innovative developments will improve efficiency by 50 $75 \%[1]$.

In their theses Syuzeva O.V. [2], as well as Yusupova S.Y. [3], referring to the Chamber of Commerce official data, noted improving in the decisions efficiency, which is calculated as the increase in profit to the increase in costs due to the controlling system introduction at industrial enterprises, stating the growth from $11 \%$ to $18.9 \%$ [2]. At the same time there is an increase in administrative staff working efficiency from $9.6 \%$ to $16 \%[2,3]$.

Another Russian research work which deals with the effectiveness of the controlling system implementation at enterprises is the thesis by Necheuhina N.S. [4], where, despite of the fact that controlling system introduction at industrial enterprises is considered only with respect to the recording at basic production, the rise of management efficiency, the efficiency of decisionmaking, as well as labor productivity increase are specially noted [2]. The growth of these indicators is comparable with the values given in the previous paper.

Yusupova S.Y. in her thesis "Theory and practice of controlling system implementation in information society" draws our attention to the fact that "the use of controlling systems for the global, strategic decisions is most effective. In this case, due to a more careful study the decisions quality and their effectiveness are getting higher, resulting in a significant increase in the management performance" [3] (Table 1).

Table 1. Long-term financial decisions efficiency based on controlling measures ${ }^{\mathrm{a}}$

\begin{tabular}{|c|c|c|}
\hline Index & $\begin{array}{c}\text { Decision quality } \\
\text { rate of growth, } \\
\text { \% }\end{array}$ & $\begin{array}{c}\text { Management } \\
\text { efficiency rate } \\
\text { of growth, \% }\end{array}$ \\
\hline $\begin{array}{c}\text { Indicator values } \\
\text { range }\end{array}$ & $18.9-43.4$ & $18.9-38.7$ \\
\hline Mean value & 34.02 & 30.98 \\
\hline Integrated Index, \% & \multicolumn{2}{|c|}{32.46} \\
\hline
\end{tabular}

Impact analysis of the controlling system introduction at foreign enterprises on the basis of research done by PricewaterhouseCoopers international company (Table 2).

Controlling system implementation efficiency at foreign industrial enterprises operating in the field of consulting and audit, has shown the trends similar to the Russian ones, although the increase in the resulting indicators of the enterprise financial and economic activity, as well as the increase in the integral index, characterizing overall indicators growth during the controlling system implementation, are less than in Russia. This trend can be explained by the fact that foreign companies have already been using the strategic management and controlling tools for a long time, as for Russia, controlling is a new development, so its first implementation has much greater output.

Table 2. Controlling system implementation efficiency at foreign industrial enterprises ${ }^{\mathrm{b}}$

\begin{tabular}{|c|c|c|}
\hline Company & $\begin{array}{c}\text { Management } \\
\text { efficiency rate of } \\
\text { growth }\end{array}$ & $\begin{array}{c}\text { Production } \\
\text { process } \\
\text { efficiency } \\
\text { rate of } \\
\text { growth }\end{array}$ \\
\hline Sony & 25.0 & 18.4 \\
\hline Samsung & 24.2 & 18.0 \\
\hline LG & 18.7 & 25.9 \\
\hline Akai & 11.8 & 8.4 \\
\hline Kodak & 11.7 & 31.9 \\
\hline Nokia & 10.2 & 25.3 \\
\hline Mazda & 9.9 & 22.9 \\
\hline Siemens & 9.3 & 21.5 \\
\hline BP & 9.1 & 19.6 \\
\hline Shell & 8.6 & 19.0 \\
\hline $\begin{array}{c}\text { AIG Brunswick } \\
\text { Capital }\end{array}$ & 7.2 & 14.9 \\
\hline $\begin{array}{c}\text { Indicator values } \\
\text { range }\end{array}$ & $7.2-25.0$ & $8.4-31.9$ \\
\hline Mean value & 13.25 & 20.53 \\
\hline $\begin{array}{c}\text { Integrated Index. \% } \\
\text { b }\end{array}$ & \multicolumn{2}{|c|}{16.49} \\
\hline \multicolumn{2}{|c|}{ Composed by the author }
\end{tabular}

The analysis of the performance indicators changes at foreign industrial companies resulting from the controlling systems introduction (Table III) enables to reveal the following positive trends in their development. Firstly, introduction of controlling enabled companies to increase the investment attractiveness level by $9 \%$ on the average (maximum increase showed by IBM Company is $34 \%$ on the average [3]. Secondly, documents circulation efficiency increased almost by $10 \%$ on the average (maximum increase showed by Mazda Company is $27.6 \%$ [3]. Thirdly, it was possible to increase the financial sustainability level by more than $8 \%$ on the average (maximum increase showed by Cristall Gross Corporation is $22.5 \%$ [3].

Other official sources of information on the controlling system introduction at foreign enterprises are the materials of the RF State Duma Financial Monitoring and Control analytical department [5] (Table 3). On the basis of these documents analysis, we can come to the conclusion that due to the controlling system introduction the investment attractiveness level increases by $8.9 \%$ on the average, documents circulation efficiency - by $9.7 \%$, financial sustainability level - by $8.3 \%$.

Thus, the analysis of investment attractiveness, documents circulation efficiency, financial sustainability rates of growth at foreign industrial companies allows us 
to conclude that controlling introduction helps to improve the situation at the enterprise and raises its efficiency.

Table 3. Dynamics of foreign industrial companies indicators due to the controlling introduction

\begin{tabular}{|c|c|c|c|}
\hline Index & $\begin{array}{c}\text { Investment } \\
\text { attractiveness } \\
\text { rate of } \\
\text { growth, \% }\end{array}$ & $\begin{array}{c}\text { Documents } \\
\text { circulation } \\
\text { efficiency } \\
\text { rate of } \\
\text { growth, \% }\end{array}$ & $\begin{array}{c}\text { Financial } \\
\text { sustainab } \\
\text { ility rate } \\
\text { of } \\
\text { growth, } \\
\text { \% }\end{array}$ \\
\hline $\begin{array}{c}\text { British } \\
\text { Petroleum }\end{array}$ & +11.4 & $+5,2$ & $+6,3$ \\
\hline Tesco & +9.3 & +11.6 & +8.9 \\
\hline $\begin{array}{c}\text { METRO } \\
\text { GROUP }\end{array}$ & +7.2 & +15.3 & +22.1 \\
\hline Cristall Gross & +6.5 & +11.3 & +22.5 \\
\hline Ford & +1.2 & +14.8 & +6.3 \\
\hline Mazda & +16.8 & +27.6 & +9.9 \\
\hline Bayer AG & +3.5 & +5.2 & +2.2 \\
\hline Schwarzkopf & +6.3 & +8.9 & +9.3 \\
\hline Oriflame & +3.3 & +9.3 & +5.7 \\
\hline Motorola & +6.8 & +9.3 & +11.0 \\
\hline Chivas & +3.9 & +1.6 & +5.2 \\
\hline Huawei & +16.5 & +11.9 & +3.5 \\
\hline Ziegler & +0.2 & +0.96 & +0.45 \\
\hline $\begin{array}{c}\text { Singer } \\
\text { Corporation }\end{array}$ & +1.6 & +2.9 & +3.6 \\
\hline Renault & +13.3 & +6.9 & +9.2 \\
\hline IBM & +33.9 & +11.8 & +6.9 \\
\hline $\begin{array}{c}\text { Indicator } \\
\text { values range c }\end{array}$ & $1.2-33.9$ & $0.96-27.6$ & $0.45-22.5$ \\
\hline Mean value c & 8.9 & 9.7 & 8.3 \\
\hline $\begin{array}{c}\text { Integrated } \\
\text { Index. \% c }\end{array}$ & & 8.95 & \\
\hline & & & c. Composed by the author \\
\hline & & & \\
\hline
\end{tabular}

And, despite the fact that the rates of growth vary in different enterprises, the trend of changes in 16 companies analyzed is positive. Therefore, conclusions are drawn that the controlling system introduction at industrial enterprises can improve business entity sustainability, which is especially important in times of crisis.

In the paper written by Borgardt E.A. and Nosova V.M., dealing with the controlling system development at OJSC "KAMAZ", the following results of the introduction are noted, "the administrative staff productivity has increased by $9.6 \%$, decision-making effectiveness has increased by $11 \%$ on the average, the long-term financial decisions effect due to the controlling measures is almost 20\%" [6].

One more example of the successful controlling system implementation is the "AT \& T Canada" company - the largest mobile operator in Canada that implemented the weighted indicators system in the company (Balanced Scorecard (BSC)). Due to the introduction the following indicators dynamics has been achieved: sales income has increased by $15 \%$, output per one worker has increased by $11 \%$, and the company market value has become 4 times higher [7].

\subsection{Basic results}

Having analyzed the research on quantitative assessment of the controlling system implementation efficiency at the company, we have come to the following conclusions.

First, all researchers have noted the positive dynamics of the enterprise financial and economic indicators as well as performance indices due to the controlling system implementation, despite the fact that controlling in the majority of papers is considered with limited functionality by performing control and recording functions or just the function of budgeting.

Second, the introduction of controlling gives from $8.7 \%$ to $18.9 \%$ increase of the decision efficiency, or $13.6 \%$ on the average.

Third, there is also an increase in administrative staff working efficiency from $9.6 \%$ to $17.2 \%$, or $13.4 \%$ on the average.

Fourth, management efficiency rises from $7.2 \%$ to $38.7 \%$, which is $18.5 \%$ on the average for the group of industrial enterprises.

Fifth, the decisions quality also increases. This increase is $34.0 \%$ on the average, ranging from $18.9 \%$ to $43.4 \%$. in different companies analyzed.

Sixth, introduction of a controlling system at the industrial plant causes production efficiency increase from $8.4 \%$ to $31.9 \%, 20.5 \%$ on the average.

Seventh, the use of the controlling system even with limited functionality has a positive effect on the overall level of the company financial sustainability. An average increase of this type of indicator is $8.3 \%$, ranging from $0.45 \%$ to $22.5 \%$.

On the basis of results generalization the integrated index of controlling system introduction efficiency at industrial enterprise has been calculated, which is $16.42 \%$.

\section{Conclusion}

The results obtained allow us to draw a definite conclusion about controlling system implementation efficiency for the enterprise, which is especially important because of economy globalization and disturbances growth in the environment. Efficiency reserves revealed during the controlling system operation should be used as a specific buffer to reduce the negative influence of environmental factors on the stability of the enterprise.

In addition, we believe that an integrated approach to the controlling system implementation in the context of both financial and economic aspects, the use of extended functionality, combining not only the control functions, recording and budgeting, but also the function of preventive management in a variable environment, based on the evidence-based simulation models will significantly increase the rate of controlling system introduction efficiency at industrial enterprise, and it will also reduce the financial and economic sustainability loss probability of mini-economic system. 
The analysis of research containing quantitative assessment of the controlling system implementation effectiveness at the company brings us to the following conclusions. Firstly, all researchers stress the positive dynamics of the enterprise financial and economic indicators owing to the controlling system implementation.

This publication was prepared within the framework of a research project №15-32-01051 supported by the Russian Humanitarian Science Foundation. The work was supported by Act 211 Government of the Russian Federation, contract № 02.A03.21.0011

\section{References}

1. S.Ya. Yusupova, Theory and practice of implementing controlling system in the information society (Moscow, 2008)

2. N.S. Necheukhina, Accounting events modeling within the system of controlling in industrial enterprises (Izhevsk, 2010)

3. S. Falco, K. Russell, L. Levin, http://www.cfin.ru/management/controlling/controlli ng.shtml.

4. O.V. Suzeva, Organisational and methodical support of controlling formation and development in industrial organizations (Moscow, 2010)

5. The information bulletin, 5, 6-9 (2006)

6. The Pricewaterhouse Cooper's bulletin, 2 (2002)

7. D.A. Yunusova, Organizational and economic mechanism of increasing economic stability of industrial enterprise (on the Republic Dagestan example) (2009)

8. Materials of Analytical Department of the State Duma of the Russian Federation for control and financial monitoring, 23-69 (2004)

9. A.N. Asaul, M.K. Starovoytov, R.A. Faltinskiy, Cost Management in construction (St. Petersburg, 2009)

10. E.A. Borgardt, V.M. Nosova, Bulletin of VSU. Series: Economics and management, 1, 108-119 (2014)

11. K.A. Sakhovskaya, N.A. Tsaplina, Modern trends in economics and management, 24, 54-58 (2014)

12. T. Hubert, S.G. Falco, Controlling, 55, 3-9 (2015)

13. A. Aroshidze, Economic Sciences, 6, 115, 30-34 (2014)

14. A. Babich, Bulletin of the Samara State University of Economics, 7(45), 10-15 (2008)

15. V. Bor, Improving stability and effectiveness management in small service businesses (2009)

16. http://www.scienceforum.ru/2014/570/4201.

17. N. Homyachenkova, Bulletin of the Tver State University. Series: Applied Mathematics, 4(37), 81$96(2010)$
18. A. Ilicheva, Developing the mechanism for evaluating sustainable development of regional industrial complex (Moscow, 2014)

19. L. Irkhina, Methodical aspects for assessing the economic stability of industrial enterprises performance (2007)

20. E. Kazyuka, Bulletin of ISEA, 4(60), 89-92 (2008)

21. A. Kanunnikov, Bulletin of OrelGIET, 1(19), 121126 (2012)

22. N. Katkova, E. Matushevskaya, BIZNES INFORM, 1, 252-257 (2015)

23. V. Kozlov, L. Danchenok, Problems in managing the stability development and business performance, (MESI, Moscow, 2012)

24. M. Makova, Bulletin of VEGU, 4(60), 53-60 (2012)

25. M. Makova, G. Husnullina, Improving economic sustainability based on the resource provision optimization, (BashGAU Publishing House, Ufa, 2007)

26. E. Nekrasova, Developing the effective development system of the enterprise (Izhevsk, 2004)

27. P. Nefedov, Formation of the enterprise for sustainable development mechanism (2010)

28. J. Persky, V. Lepihin, E. Semenova, Bulletin of Perm University. Series: Economics, 1(24), 103-110 (2015)

29. E. Slabinsky, National Academy of Sciences of Ukraine.http://dspace.nbuv.gov.ua/bitstream/handle/ 123456789/4403/st_26_23.pdf? sequence $=1$.

30. V. Strokov, Engineering magazine: Science and Innovations, 11, 11, 199-211 (2012)

31. Y. Suleymanova, Management Issues, 2(19), 224229 (2012)

32. T.A. Khudyakova, A.V. Shmidt, Proc. of The 26th International Business Information Management Association Conference, 1626-1634 (2015)

33. T.A. Khudyakova, Actual problems of economics, 12, 444-450 (2015)

34. B. Schurov, M. Dmitriev, Humanitarian, socioeconomic and social sciences, (2015). http://www.onlinescience.ru/m/products/economi_sciense/gid2918/pg $0 /$

35. E. Wetzel, Probability Theory (Nauka, Moscow, 1969)

36. D. Yunusova, Organizational and economic mechanism to increase the economic stability of an industrial enterprise (based on the Republic Dagestan example) (Makhachkala, 2009)

37. O. Zaitcev, Proc. Papers of Russian Scientific and Practical Congress: Problems of Economics and Statistics at the national and regional scales (2006) 